Génét. Sél. Evol., 1985, 17 (1), 59-72

\title{
Allozyme frequency changes in two inverse sequences of environments in Drosophila melanogaster
}

\author{
H. MERÇOT \\ Laboratoire de Génétique des Populations, tour 42, Université Paris 7 \\ 2, place Jussieu, F 75005 Paris
}

\begin{abstract}
Summary
Six replicates of a Drosophila melanogaster population were confronted with 2 sequences of 3 different environments, to wit 3 replicates with the environmental sequence E1-E2-E3 characterizing the H1 history and 3 replicates with the inverse sequence E3-E2-E1 characterizing the $\mathrm{H} 3$ history. The 6 replicates maintained in population cages were exposed to each environment for 5 discrete generations. Changes in allozyme frequencies, at 4 loci, were analysed to detect whether the changes depended upon the order of succession of the 3 environments. This was only the case for one locus, $A d h$, but not for Est-6 and Pgm, and can be related to the sensitivity of the Adh locus to environmental diversity. For the last locus, $\alpha-G p d h$, the substantial heterogeneity between replicates within each history seems to be due to a hitchhiking effect.

The diversity of the observed evolutionary profiles, more important between loci for a same history than between the 2 histories for a same locus, seems to point to a set of genetic interactions peculiar to each locus.
\end{abstract}

Key-words : Environmental diversity, enzyme polymorphism, Drosophila melanogaster, partition of $\chi^{2}$.

\section{Résumé}

Variations de fréquences allozymiques dans deux séries inverses d'environnements chez Drosophila melanogaster

Trois répliques d'une population de Drosophila melanogaster ont été confrontées à une séquence de 3 environnements différents, caractérisant l'histoire H1. Simultanément, 3 autres répliques de cette population ont été confrontées à la séquence inverse des 3 environnements, caractérisant l'histoire H3. Les 6 répliques ont été gardées, en cage à population, 5 générations discrètes par environnement. A l'aide de la méthode de décomposition du $\chi^{2}$, les variations de fréquences allozymiques à 4 locus ont été analysées afin de voir si celles-ci dépendaient ou non de l'ordre de succession des 3 environnements. C'est le cas pour le seul locus de l'Adh, contrairement à ceux de l'Est-6 et de la Pgm. Ce résultat est mis en relation avec la sensibilité du locus $A d h$ à la diversité environnementale. Pour le dernier locus, l'a-Gpdh, la grande hétérogénéité des résultats intra-histoire pourrait être due à un effet «hitch-hiking». 
Quant à la diversité des profils évolutifs obtenus, plus grande entre locus pour une même histoire qu'entre les 2 histoires pour un même locus, elle semble témoigner d'un contexte d'interactions géniques particulier à chacun des locus.

Mots clés : Diversité de l'environnement, polymorphisme enzymatique, Drosophila melanogaster, décomposition $d u \chi^{2}$.

\section{Introduction}

In a theoretical article on the "Principle of Historicity in Evolution », LEwoNTIN (1967) investigated the pattern of changes in the allelic frequencies of a diallelic locus submitted to 2 reverse sequences of environments. The simulations showed that the pattern of variation of the allelic frequencies over time were different according to the order of the successive environments. Thus, specific selection coefficients for each environment being chosen at random and the allelic frequencies being equal (0.50) at the start of each simulation, the frequency of the reference allele was more often below 0.50 with one of the environmental sequences, more often above 0.50 with the reverse sequence. LEWONTIN emphasized that 2 populations living in precisely the same kind of environment - i.e. one in which the probability of selection in a given direction has the same distribution - will nevertheless have totally different life histories.

In the present study we have tested experimentally LEwONTIN's schema using a population of Drosophila melanogaster maintained during 5 generations in each of $j$ successive environments. The environmental sequence E1-E2-E3 characterized the $\mathrm{H} 1$ history and the inverse sequence E3-E2-E1 the $\mathrm{H} 3$ history. The variations in allozyme frequencies at 4 loci ( $\alpha$-Glycerophosphate dehydrogenase, Alcohol dehydrogenase, Esterase-6 and Phosphoglucomutase) were followed in order (a) to determine whether or not they were dependent on the order of the 3 successive environments (i.e. history) and (b) to analyse the pattern of variations over time (i.e. generations).

\section{Material and methods}

\section{A. Experimental population}

The population of $D$. melanogaster used in this experiment was SA-FIV. It was constituted in 1979 with 200 pairs of adults derived from a stock obtaincd, in 1977, from 21 isofemale lines, found to be inversion free (Tоко \& CHARLESwORTH, 1982). These isofemale lines were from a population collected, in 1975, by P.T. IVES, in South Amherst, Massachusetts, USA.

\section{B. Environmental conditions}

Six population cages $(36 \times 16 \times 9 \mathrm{~cm}$ plastic boxes $)$ were started, each receiving 2400 adult flies : 3 cages (H1A, H1B, H1C) were used to test the H1 history, i.e. the 
effect of the environmental succession E1-E2-E3 and 3 others to test the H3 history, i.e. the environmental sequence E3-E2-E1. The 6 cages were maintained for 5 discrete generations in each successive environment, whose characteristics were the following :

E1 : discrete 15-day generation, a temperature of $25^{\circ} \mathrm{C}$, a relative humidity (RH) of 50 p. 100. Females allowed to lay eggs during $30 \mathrm{~h}$ on 20 vials containing $20 \mathrm{cc}$ of S101 medium (PEARL et al., 1926) with live yeast.

E2 : discrete 25 -day generation, $18^{\circ} \mathrm{C}$, RH of 60 p. 100,3 days for egg laying on 15 vials containing $20 \mathrm{cc}$ of $\mathrm{S} 101$ medium with live yeast.

E3 : discrete 25 -day generation, $18^{\circ} \mathrm{C}, \mathrm{RH}$ of 60 p. 100,3 days for egg laying on 15 vials containing $30 \mathrm{cc}$ of axenic medium - cornmeal $35 \mathrm{~g}$, killed yeast $35 \mathrm{~g}$, Agar $10 \mathrm{~g}$, Nipagine $5 \mathrm{~g}$, water 1 liter (from David, 1959) - supplemented with $100 \mathrm{cc}$, per liter, of ethanol added at $50^{\circ} \mathrm{C}$ and mixed vigorously. The mixture was then poured into vials, stored at $6^{\circ} \mathrm{C}$ and used for egg laying from 5 to $6 \mathrm{~h}$ later.

As a control, the SA-FIV population was maintained at $18^{\circ} \mathrm{C}$ in 12 bottles, mixed at each generation, on cornmeal medium with live yeast. These " keeping " conditions (KC) of the population were supposed to guarantee minimum disturbance for the population.

\section{Electrophoresis}

Electrophoretic assays were conducted on horizontal starch gel (CoNNAuGHT) using discontinuous Poulik buffer system (Poulik, 1957). Four polymorphic loci were analysed : $\alpha$-Glycerophosphate dehydrogenase, $\alpha-G p d h$ (2-20.5) ; Alcohol dehydrogenase, Adh (2-50.1) ; Esterase-6, Est-6 (3-36.8) ; Phosphoglucomutase, Pgm (343.4). The staining methods were adapted from Ayala et al. (1972).

Two allozymes segregate at the $\alpha-G p d h\left(G p d h^{s}, G p d h^{F}\right), A d h\left(A d h^{S}, A d h^{F}\right)$ and Est-6 $\left(\right.$ Est $-6^{S}=E s t-6^{1.00}$, Est-6F $=$ Est $\left.-6^{1.10}\right)$ loci, and 3 at the Pgm locus $\left(P_{g m^{S}}=\mathrm{Pgm}^{0.70}, \mathrm{Pgm}^{\mathrm{F}}=\mathrm{Pgm}^{1.00}, \mathrm{Pgm}^{V}=\mathrm{Pgm}^{1.20}\right)$ (Correspondence for the alleles from OAKESHOTT et al., 1981, 1982).

\section{Statistical analysis}

The data comprise a sequence of allozyme frequencies $\left\{\mathrm{p}_{\mathrm{k}, \mathrm{hr}}\right\}$ where $\mathrm{p}_{\mathrm{g}, \mathrm{hr}}$ is the allozyme frequency in the $\mathrm{g}^{\text {th }}$ generation $(\mathrm{g}=0,1,5,6,10,11,15)$ for the history $\mathrm{h}$ $(\mathrm{h}=1$ for $\mathrm{H} 1,3$ for $\mathrm{H} 3)$ in the replicate $\mathrm{r}(\mathrm{r}=\mathrm{A}, \mathrm{B}, \mathrm{C})$. For $90 \mathrm{p} .100$ of the $\mathrm{p}_{\mathrm{g}, \mathrm{hr}}$ values, the estimates were obtained from 150 to 180 adult flies (sex ratio $\simeq 1: 1$ ) collected after the oviposition period.

The variation in allozyme frequencies at a locus was analysed in respect of generations, histories and replicate populations using the partition of $\chi^{2}$ test (LANCASTER, 1949, 1950 ; IRWIN, 1949). This test provides, for discrete variables, a statistical analysis similar to the test of ANOVA (WINER, 1971), using the observed and expected allelic numbers and not a transformation of the allelic frequencies.

Four factors were considered in the analysis : allele ( $f$ ), generation $(G)$, history (H) and replicate $\left(R_{h}\right)$ within each history, with $\alpha$ alleles, $\gamma$ generations, $ı$ histories, $\varrho_{1}$ replicates for $\mathrm{H} 1, \varrho_{3}$ replicates for $\mathrm{H}_{3}\left(\varrho_{1}+\varrho_{3}=\varrho\right)$. The contingency table 
contains " $\alpha$ columns and $\gamma \cdot \varrho$ rows. Because the observed and expected marginal totals are fixed, the number of degrees of freedom (d.f.) for the $\chi^{2}$ of total homogeneity is $\{(\gamma \cdot \varrho)-1\} \cdot(\alpha-1)$; the overall value of this total $\chi^{2}$ was partitioned into additive values of component $\chi^{2}$ testing the different possible sources of variation of the allozyme frequencies (tabl.2). In this table, these sources of variation of allozyme frequencies of any one locus represent :

Generation effect $(G \times f)$ with $(\gamma-1)(\alpha-1)$ d.f. : homogeneity of $\mathrm{p}_{\mathrm{g} \ldots}$ over generations, irrespective of histories and replicates ;

History effect $(\mathrm{H} \times \mathrm{f})$ with $(\mathrm{\imath}-1)(\alpha-1)$ d.f. : homogeneity of p..h. over histories irrespective of generations and replicates;

Interaction Generations $\times$ histories $(G \times H \times f)$ with $(\gamma-1)(t-1)(\alpha-1)$ d.f. : homogeneity of $p_{g, h}$. over generations conditional upon histories irrespective of replicates ;

Replicate effect $\left(R_{1} \times f\right)$ with $\left(\varrho_{1}-1\right)(\alpha-1)$ d.f. and $\left(R_{3} \times f\right)$ with $\left(o_{3}-1\right)$ $(\alpha-1)$ d.f. : homogeneity of $p_{. .11 \text { r }}$ over replicates irrespective of generations within both $\mathrm{H} 1$ and $\mathrm{H} 3$ histories;

Interaction Generations $\times$ replicates $\left(G \times R_{h} \times f\right)$ with $(\gamma-1)\left(\varrho_{11}-1\right)(\alpha-1)$ d.f. : homogeneity of $p_{k . h r}$ over generations conditional upon replicates within both $\mathrm{H} 1$ and $\mathrm{H} 3$ histories.

In order to itemize, for all generations, the replicate effect within $\mathrm{H} 1$ and $\mathrm{HJ}$ and the history effect, the component $\chi^{2}$ testing these effects, generation by generation, were computed (tabl. 3) with $\left(\varrho_{\mathrm{I}}-1\right)(\alpha-1),\left(\varrho_{3}-1\right)(\alpha-1)$ and $(1-1)$ $(\alpha-1)$ d.f. respectively. This $2^{n d}$ partition of $\gamma^{2}$ was concluded with the computation of the component $\chi^{2}$ testing the generation effect in each history $\left(G_{11} \times f\right)$ with $(\gamma-1)(\alpha-1)$ d.f. When necessary, some other component $\chi^{2}$ are presented in the text to compare any other particular frequencies.

The formulas used for the calculations of the component $\chi^{2}$ in a partition were those given by Kimball (1954) and Maxwell (1961).

\section{Results}

Figures 1 through 4 show the allozyme frequencies observed in each replicate of both histories and table 1 the allelic frequencies of the control population maintained in the "keeping " conditions $(\mathrm{KC})$.

For each locus, the overall $\chi^{2}$ value is very significant (tabl. 2). The partitioning of these values (tabl. 2 and 3) allowed us to determine the sources of variation causing this high heterogeneity in the allozyme frequencies.

\section{A. Generation effect $\left(\mathrm{G} \times \mathrm{f}\right.$ and $\left.\mathrm{G}_{11} \times \mathrm{f}\right)$}

The component $\chi^{2}$ testing the average frequency changes during generations is highly significant for the 4 loci in both histories (tabl. 3). For $\ddot{\alpha}$ - $G$ pdh and Est-6 loci, this variation contrasts with the stability observed in the KC (tabl. 1). For Adh, the 
$A d h^{F}$ frequency increased in both histories but decreased in the $\mathrm{KC}$, whereas, for $P g m$, the allelic frequencies changed in a similar manner in both histories and in the $\mathrm{KC}\left(\mathrm{Pgm}^{\mathrm{F}}\right.$ increased, $\mathrm{Pgm}^{V}$ decreased and $\mathrm{Pgm}^{S}$ decreased or remained stable).
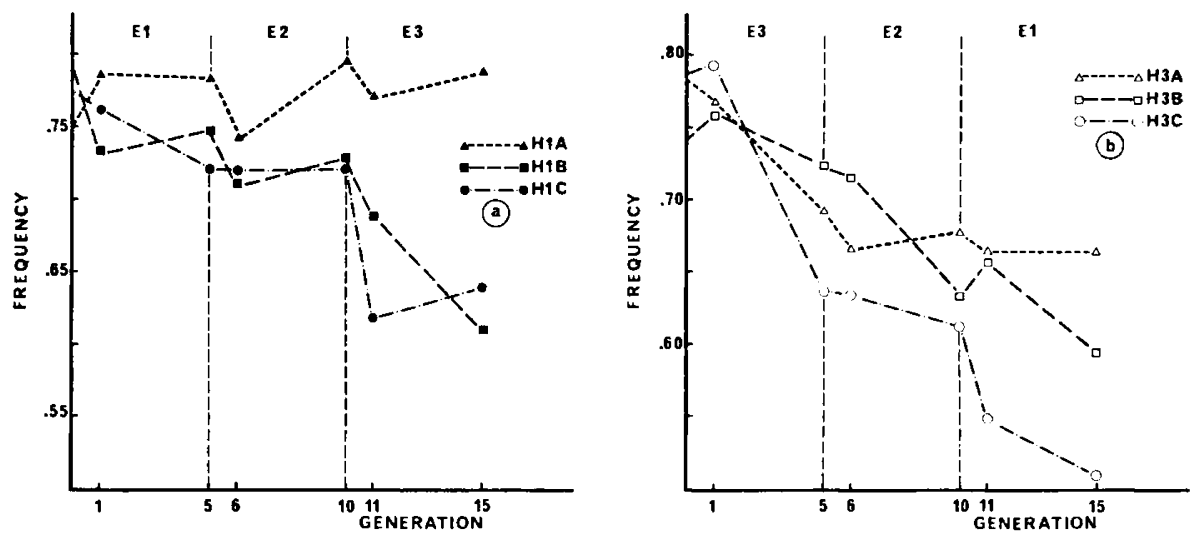

FIG. 1

GpdhF frequencies for the replicate populations submitted :

a) to the $\mathrm{HI}$ history (sequence E1-E2-E3 of environments),

b) to the H3 history (sequence E3-E2-El of environments).

Fréquences de l'allèle $\mathrm{Gpdh} F$ dans les répliques de la population soumises :

a) à l'histoire $H 1$ (séquence E1-E2-E3 des environnements),

b) à l'histoire $H 3$ (séquence E3-E2-El des environnements).
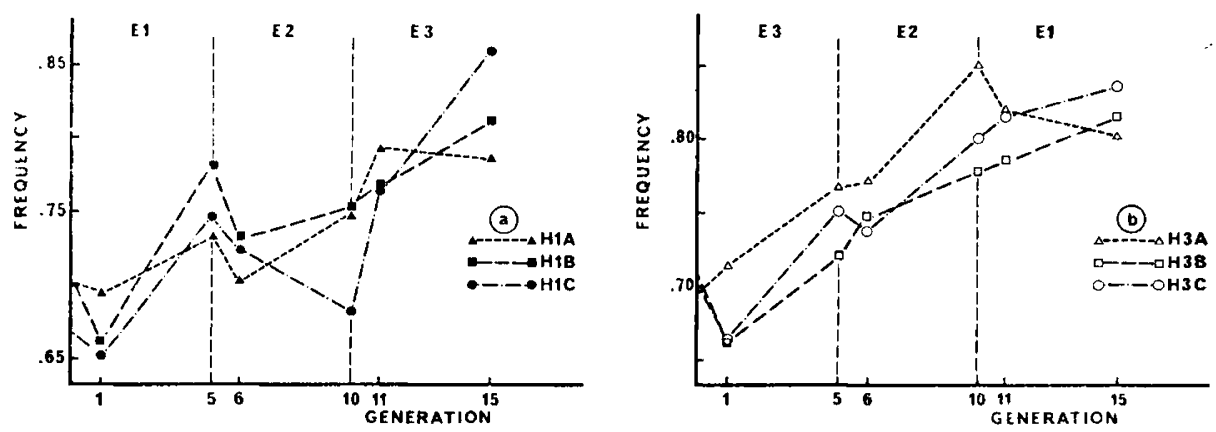

FIG. 2

AdhF frequency data : same presentation as in figure 1 .

Fréquences de l'allèle $\mathrm{Adh} \mathrm{F}$ : même présentation qu'à la figure 1. 

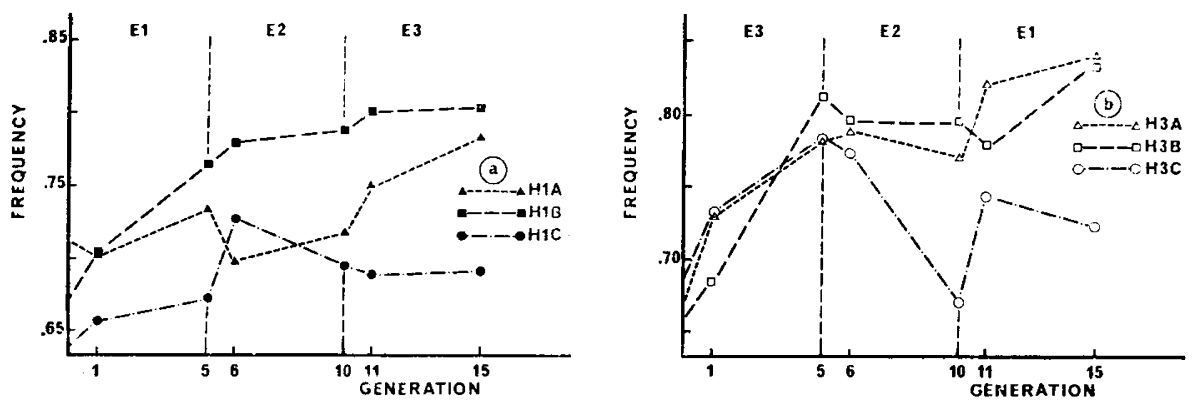

Fig. 3

Est-6 $\mathrm{F}$ frequency data : same presentation as in figure 1.

Fréquences de l'allèle Est-6 $\mathrm{F}$ : même présentation qu'à la figure 1.
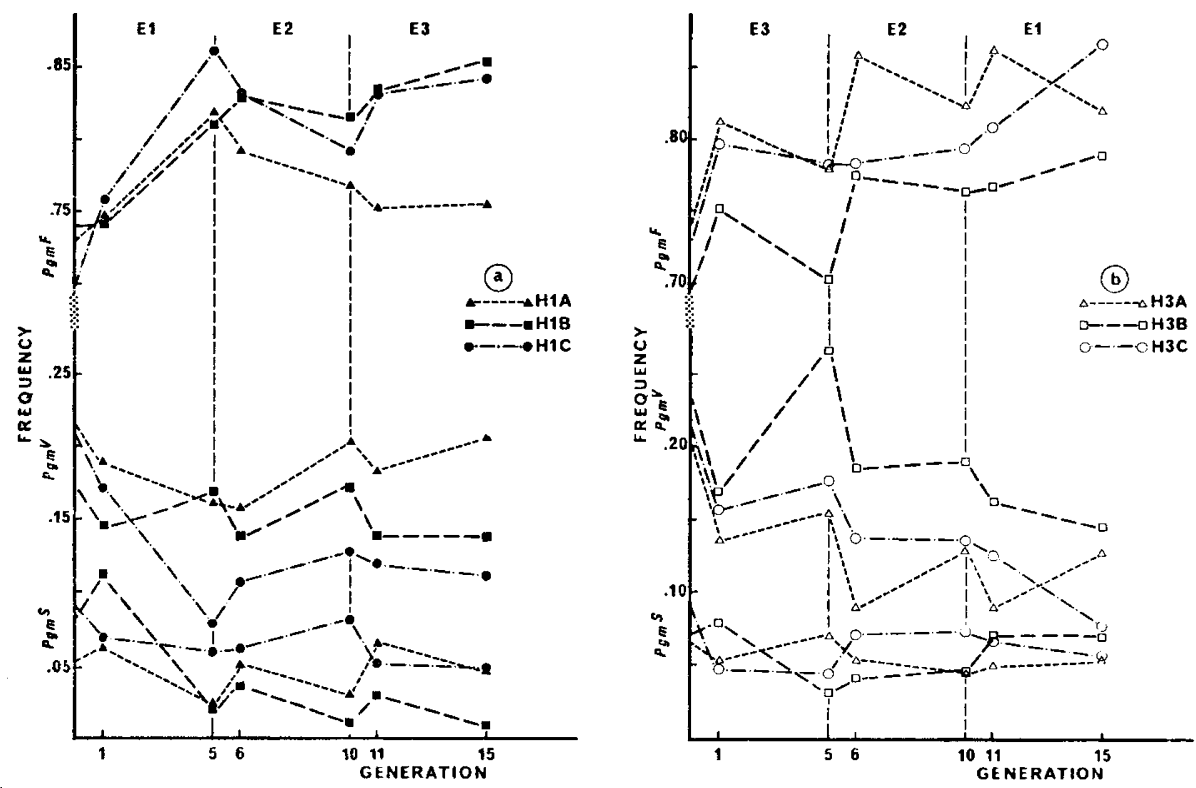

Fig. 4

$\mathrm{Pgm}^{\mathrm{S}}, \operatorname{Pgm} \mathrm{V}$ and $\mathrm{Pgm} \mathrm{F}$ frequency data : same presentation as in figure 1 .

Fréquences des allèles $\mathrm{Pgm} \mathrm{S}, \mathrm{Pgm}^{\mathrm{V}}$ et $\mathrm{Pgm} \mathrm{F}$ : même présentation qu'à la figure 1 .

\section{B. Replicate effect $\left(\mathrm{R}_{\mathrm{l}} \times \mathrm{f}\right.$ and $\left.\mathrm{G} \times \mathrm{R}_{\mathrm{h}} \times \mathrm{f}\right)$}

This analysis tests whether the frequency changes from generation to generation were identical between the 3 replicate populations within each history and, conse- 
quently, may detect the possible existence of a random drift and its eventual consequences. All loci, except $A d h$ (fig. 2), display an intra-history heterogeneity (tabl. 2 and 3).

\section{TABLE 1}

Allozyme frequencies for $\mathrm{Gpdh} F, \mathrm{AdhF}$, Est-6F, PgmV and $\mathrm{Pgm}^{F}$ in the keeping conditions $(K C)$ of the population and $\chi^{2}$ of frequency homogeneity.

Fréquences des allèles $\mathrm{Gpdh} F$, AdhF, Est-6F, Pgm $\mathrm{V}$ et $\mathrm{Pgm} F$

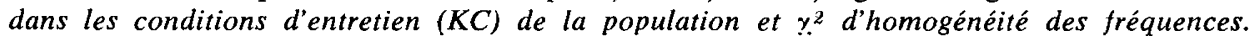

\begin{tabular}{|c|c|c|c|c|c|c|}
\hline & Generation & $G p d h^{F}$ & $A d h^{F}$ & Est-6F & $P g m^{V}$ & $P g m^{F}$ \\
\hline 0 & $\ldots \ldots \ldots \ldots$ & $\begin{array}{c}.771 \\
(.014)\end{array}$ & $\begin{array}{c}.702 \\
(.015)\end{array}$ & $\begin{array}{c}.672 \\
(.015)\end{array}$ & $\begin{array}{c}.216 \\
(.014)\end{array}$ & $\begin{array}{c}.710 \\
(.015)\end{array}$ \\
\hline 1 & & $\begin{array}{c}.774 \\
(.013)\end{array}$ & $\begin{array}{c}.690 \\
(.015)\end{array}$ & $\begin{array}{c}.674 \\
(.015)\end{array}$ & $\begin{array}{c}.199 \\
(.013)\end{array}$ & $\begin{array}{c}.725 \\
(.014)\end{array}$ \\
\hline 6 & $\ldots \ldots \ldots \ldots$ & $\begin{array}{c}.742 \\
(.025)\end{array}$ & $\begin{array}{c}.656 \\
(.027)\end{array}$ & $\begin{array}{c}.707 \\
(.027)\end{array}$ & $\begin{array}{c}.215 \\
(.024)\end{array}$ & $\begin{array}{c}.702 \\
(.026)\end{array}$ \\
\hline 10 & $\ldots$ & $\begin{array}{c}.700 \\
(.026)\end{array}$ & $\begin{array}{c}.597 \\
(.027)\end{array}$ & $\begin{array}{c}.641 \\
(.027)\end{array}$ & $\begin{array}{c}.178 \\
(.021)\end{array}$ & $\begin{array}{c}.759 \\
(.024)\end{array}$ \\
\hline 14 & & $\begin{array}{c}.759 \\
(.025)\end{array}$ & $\begin{array}{c}.582 \\
(.029)\end{array}$ & $\begin{array}{c}.643 \\
(.028)\end{array}$ & $\begin{array}{c}.114 \\
(.018)\end{array}$ & $\begin{array}{c}.799 \\
(.023)\end{array}$ \\
\hline 18 & & $\begin{array}{c}.734 \\
(.025)\end{array}$ & $\begin{array}{c}.642 \\
(.028)\end{array}$ & $\begin{array}{c}.661 \\
(.027)\end{array}$ & $\begin{array}{c}.123 \\
(.019)\end{array}$ & $\begin{array}{c}.801 \\
(.023)\end{array}$ \\
\hline 25 & . & $\begin{array}{c}.731 \\
(.025)\end{array}$ & $\begin{array}{l}.630 \\
(.027)\end{array}$ & $\begin{array}{l}.630 \\
(.026)\end{array}$ & $\begin{array}{c}.085 \\
(.015)\end{array}$ & $\begin{array}{c}.852 \\
(.020)\end{array}$ \\
\hline 34 & .. & $\begin{array}{c}.780 \\
(.025)\end{array}$ & $\begin{array}{c}.609 \\
(.040)\end{array}$ & $\begin{array}{c}.716 \\
(.028)\end{array}$ & $\begin{array}{c}.087 \\
(.017)\end{array}$ & $\begin{array}{c}.864 \\
(.021)\end{array}$ \\
\hline$\chi^{2}$ & & 11.38 & 29.21 & 9.19 & & 72.35 \\
\hline \multirow[t]{2}{*}{ d.f. } & & 7 & 7 & 7 & & 14 \\
\hline & & N.S. & $\mathrm{p}<.001$ & N.S. & & $\mathrm{p}<.001$ \\
\hline
\end{tabular}

Standar errors are in parentheses.

Erreurs standards entre parenthèses.

1) $\alpha-G p d h$ locus (fig. 1) : the replicate effect and the $\mathrm{G} \times \mathrm{R}_{\mathrm{h}} \times \mathrm{f}$ interaction are very significant in both histories (tabl. 2). The intra-history heterogeneity started between generations 10 and 11 (tabl. 3), that is, in the early part of the E3 environment for the $\mathrm{H} 1$ history and of the $\mathrm{E} 1$ environment for the $\mathrm{H} 3$ history. 
For $\mathrm{H} 1$, the replicate $\mathrm{A}$ in which the $G p d h^{F}$ frequency is the highest (fig. 1 a) accounts for all this divergence $\left(p_{. .1 n}\right.$ versus $p_{. .1}: \chi_{1}^{2}=0.33 ;$ ns and $p_{. .1 p+c} v s$ p..1A $\left.: \chi_{1}^{2}=29.11 ; \mathrm{p}<.001\right)$. Moreover, the $G p d h^{F}$ frequency did not vary in this replicate $\left(\chi_{6}^{2}=3.60 ; \mathrm{ns}\right)$.

For H3, all the divergence is due to the replicate $C\left(p_{\ldots a} v s p_{\ldots 3}: \chi_{1}^{2}=1.90\right.$. $\mathrm{ns}$, and $\mathrm{p}_{., 3 \mathrm{~A}+\mathrm{b}}$ vs $\left.\mathrm{p}_{., 3 \mathrm{c}}: \chi_{1}^{2}=18.16 ; \mathrm{p}<.001\right)$ in which the $G p d h^{F}$ frequency is the lowest (fig. $1 \mathrm{~b}$ ).

2) Est-6 locus (fig. 3) : the replicate effect is significant in both histories (tabl. 2) but the intra-history divergence, manifest from generation 10 onward (tabl. 3), is less pronounced than for $\alpha-G p d h$.

In $\mathrm{H} 1$ (fig. $3 \mathrm{a}$ ), the divergence is chiefly due to the replicate $\mathrm{C}\left(\mathrm{p}_{., 1 \mathrm{~A}}\right.$ vs $\mathrm{p}_{., 1 \mathrm{~B}}$ : $\chi_{1}^{2}=5.10 ; \mathrm{p}<.05$, and $\mathrm{p}_{., 1 \mathrm{~A}+\mathrm{B}}$ vs $\left.\mathrm{p}_{., 1 \mathrm{C}}: \chi_{1}^{2}=12.96 ; \mathrm{p}<.001\right)$ in which the Est- ${ }^{F}$ frequency is the lowest. Yet, the absence of significance for the $G \times R_{1} \times f$ interaction (tabl. 2) denotes, for this locus, a similar evolutionary profile of the 3 replicates.

For $\mathrm{H} 3$ (fig. $3 \mathrm{~b}$ ), replicate $\mathrm{C}$, in which the Est- $6^{F}$ frequency is also the lowest, diverged $\left(\mathrm{p}_{., 3 \mathrm{~A}}\right.$ vs $\mathrm{p}_{., 3 \mathrm{~B}}: \chi_{1}^{2}=0.01 ; \mathrm{ns}$, and $\mathrm{p}_{., 3 \mathrm{~A}+\mathrm{B}}$ vs $\left.\mathrm{p}_{., 3 \mathrm{C}}: \chi_{1}^{2}=11.19 ; \mathrm{p}<.001\right)$. The heterogeneity between replicates seems greater in $\mathrm{H} 3$ than in $\mathrm{H} 1$ since the $\mathrm{G} \times \mathrm{R}_{3} \times \mathbf{f}$ interaction is significant (tabl. 2).

The origin of the intra-history heterogeneity, for the $\alpha-G p d h$ and Est-6 loci is likely to be due to the decrease in the population size observed from generations 8 to 10 for $\mathrm{H} 1$, from generations 6 to 8 for H3. During these periods the hatching of the eggs and the development of first-instar larvae were rendered difficult by filaments of mould which developed on the surface of the S101 medium vials. Consequently, the number of adult flies emerging in most cages was reduced to about 300-400 individuals. The effective population size may have become small enough to induce a genetic drift that might explain some results obtained from generation 10 onward.

3) Pgm locus (fig. 4) : the above hypothesis cannot be the sole explanation for the replicate effect already obvious in generation 5 in both histories (tabl. 3).

During the $\mathrm{H} 1$ history, the 3 replicates are heterogeneous ( $\mathrm{p}_{., 1 \mathrm{~A}}$ vs $\mathrm{p}_{., 1 \mathrm{~B}}$ : $\chi_{2}^{2}=12.00 ; \mathrm{p}<.01, \mathrm{p}_{., 1 \mathrm{~B}}$ vs $\mathrm{p}_{., 1 \mathrm{C}}: \chi_{2}^{2}=18.15 ; \mathrm{p}<.001$, and $\mathrm{p}_{., 1 \mathrm{~A}}$ vs $\mathrm{p}_{., 1 \mathrm{C}}:$ $\left.\chi_{2}^{2}=9.73 ; \mathrm{p}<.01\right)$, but as for the $\alpha-G p d h$ locus it is replicate $\mathrm{A}$ which shows the larger divergence after generation 10 (fig. 4 a). And the significant $G \times R_{1} \times f$ interaction (tabl. 2) confirm this heterogeneity.

During the $\mathrm{H} 3$ history the heterogeneity is less pronounced : the $\mathrm{G} \times \mathrm{R}_{3} \times \mathrm{f}$ inferaction is not significant (tabl. 2) and 2 replicates, $A$ and $C$, are homogeneous $\left(\chi_{2}^{2}=3.78 ; n s\right)$ whereas replicate $C$ is not $\left(\mathrm{p}_{., 3 \mathrm{~A}+\mathrm{C}}\right.$ vs $\left.\mathrm{p}_{., 3 \mathrm{~B}}: \chi_{2}^{2}=29.73 ; \mathrm{p}<.001\right)$. Finally, if the replicate effect is significant for generations 5 and 6 , this is no longer the case from generation 10 onward (tabl. 3). 


\section{TABLE 2}

Partition of total frequency homogeneity $\chi^{2}$ for each locus.

Décomposition $d u \chi^{2}$ total d'homogénéité des fréquences pour chaque locus.

\begin{tabular}{|c|c|c|c|c|c|}
\hline \multirow{2}{*}{ Source of variation } & \multicolumn{4}{|c|}{ Value of component $\chi^{2}$} & \multirow{2}{*}{ d.f. $\dagger$} \\
\hline & $\alpha G p d h$ & $A d h$ & Est -6 & Pgm & \\
\hline Generation effect : $\mathrm{G} \times \mathrm{f} \ldots \ldots$ & $144.4^{* * *}$ & $158.0^{* * * *}$ & $91.7 * * *$ & $97.8 * * *$ & 6 \\
\hline History effect : $\mathbf{H} \times \mathbf{f}$ & $53.5^{* * * *}$ & $8.6^{* *}$ & $23.3 * * *$ & 5.2 & 1 \\
\hline Interaction : $\mathrm{G} \times \mathrm{H} \times \mathrm{f}$. & $35.1 * * *$ & $13.5 *$ & 6.0 & $32.5^{* * *}$ & 6 \\
\hline H1 : Replicate effect : $\mathrm{R}_{1} \times \mathrm{f} \ldots$ & $29.4 * * *$ & 1.4 & $35.4^{* * *}$ & $41.3^{* * *}$ & 2 \\
\hline Interaction : $\mathrm{G} \times \mathbf{R}_{1} \times \mathbf{f} \ldots$ & $32.7 * *$ & 16.1 & 15.6 & $46.4 * *$ & 12 \\
\hline $\begin{aligned} \text { H3 : } & \text { Replicate effect : } R_{3} \times f \ldots \\
& \text { Interaction }: G \times R_{3} \times \mathbf{f} \ldots\end{aligned}$ & $\begin{array}{l}20.1 * * * \\
29.2 * *\end{array}$ & $\begin{array}{l}4.3 \\
8.5\end{array}$ & $\begin{array}{l}11.2 * * * \\
23.8^{*}\end{array}$ & $\begin{array}{l}33.5 * * * \\
32.4\end{array}$ & $\begin{array}{r}2 \\
12\end{array}$ \\
\hline Total & $344.4 * * *$ & $210.4 * * *$ & $207.0^{* * *}$ & $289.1 * * *$ & 41 \\
\hline
\end{tabular}

$* \mathrm{p}<.05-* * \mathrm{p}<.01-* * * \mathrm{p}<.001$.

$\dagger$ : The number of d.f. is twice for Pgm.

Le nombre de d.d.l. est double pour le locus Pgm.

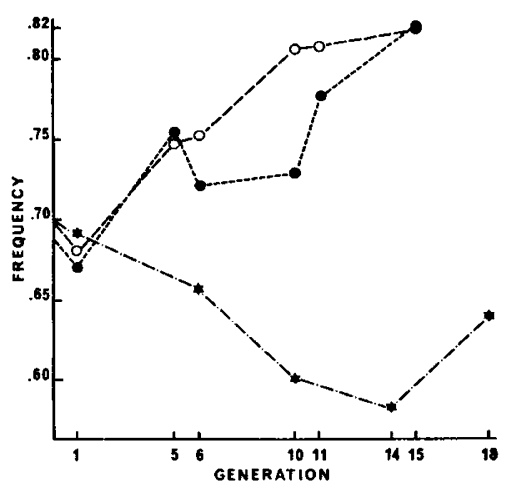

FIG. 5

Changes in $\mathrm{Adh} F$ mean frequency during the $H 1$ history $\left(p_{g, 1}\right)(\bullet)$, the $H 3$ history $\left(p_{g, 3}\right)(O)$, and in the keeping conditions $(\star)$ of the $S A-F I V$ population.

Variations de la fréquence moyenne de l'allèle $\mathrm{Adh} F$ durant l'histoire $H 1\left(p_{g, 1}\right)(\bullet)$, l'histoire $H 3\left(p_{g, 3}\right)(O)$, et dans les conditions d'entretien $(\star)$ de la population SA-FIV. 


\section{TABLE 3}

Value, for each locus, of component $\chi^{2}$ corresponding to : - replicate effect $(2$ d.f.) in the $\mathrm{H} 1$ and $\mathrm{H} 3$ histories for each generation $(g)$, - history effect $\left(\begin{array}{ll}1 & \text { d.f.) }\end{array}\right)$ for each generation $(g)$, - generation effect $\left(6\right.$ d.f.) in the $H I\left(G_{1} \times f\right)$ and $\mathrm{H}_{3}\left(G_{3} \times f\right)$ histories.

Valeur, pour chaque locus, des $\chi^{2}$ constitutifs correspondant à : - l'effet réplique (2 d.d.l.) à chaque génération $(\mathrm{g})$ dans les histoires $\mathrm{HI}$ et $\mathrm{H3}$. - l'effet histoire (1 d.d.l.)

à chaque génération $(g)$, - l'effet génération $\left(6\right.$ d.d.l.) dans les histoires $H 1\left(G_{1} \times f\right)$ et $\mathrm{H3}\left(\mathrm{G}_{3} \times f\right)$.

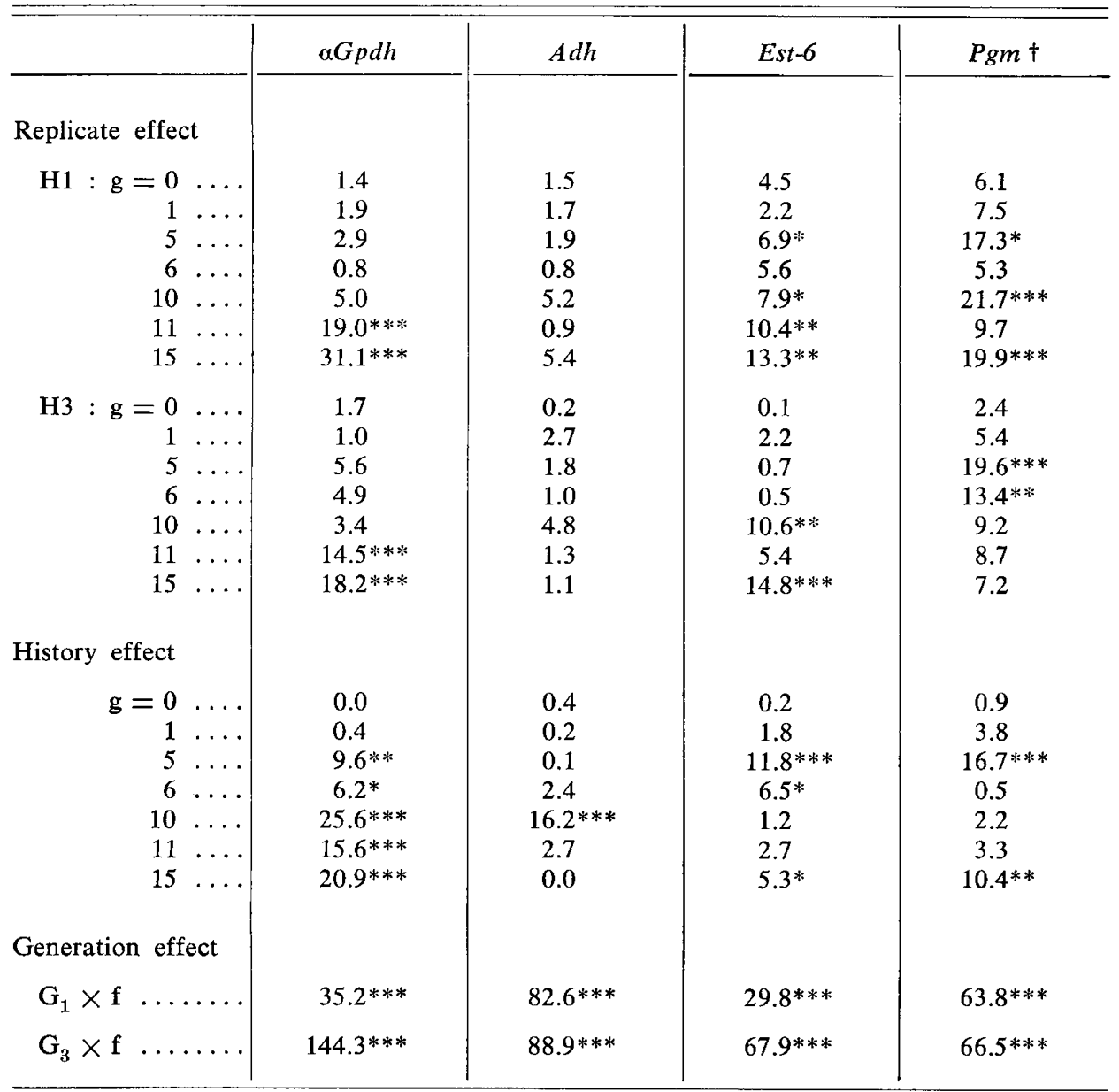

$* \mathrm{p}<.05-* * \mathrm{p}<.01-* * * \mathrm{p}<.001$.

$\dagger$ : The number of d.f. is twice for Pgm.

Le nombre de d.d.l. est double pour le locus Pgm. 


\section{History effect $(\mathrm{H} \times \mathrm{f}$ and $\mathrm{G} \times \mathrm{H} \times \mathrm{f})$}

The analysis of this effect shows whether the changes in allozyme frequency depended upon the order of succession of the 3 environments. The results are different for the four loci.

1) $A d h$ locus (fig. 5): though in generation 15 the average frequency is identical between the 2 histories $\left(\mathrm{p}_{15,1}=0.820\right.$ and $\left.\mathrm{p}_{15,3}=0.818\right)$, the $A d h^{F}$ frequency behavior appears to depend upon the succession of environments. Thus, the history effect is significant as well as the $\mathrm{G} \times \mathrm{H} \times \mathrm{f}$ interaction (tabl. 2). The generation by generation comparison (tabl. 3)shows that the history effect is due to a divergent response to the $\mathrm{E} 2$ environment. This environment was experienced by the flies after 5 generations in the $\mathrm{E} 1$ or in the $\mathrm{E} 3$ environment with similar mean frequencies $\left(p_{5,1}=0.754\right.$ and $\left.p_{5,3}=0.746\right)$. However, after 5 generations in the E2 environment (i.e. at generation 10), the $A d h^{F}$ mean frequency has remained stable in the $\mathrm{H} 1$ history $\left(\mathrm{p}_{10.1}=0.727, \chi_{1}^{2}=1.79 ; \mathrm{ns}\right)$ but has increased in the $\mathrm{H} 3$ history $\left(\mathrm{p}_{10.3}=0.806, \chi_{1}^{2}=9.19 ; \mathrm{p}<.01\right)$.

The $A d h^{F}$ frequency behavior differed whether the population experienced the $\mathrm{H} 1$ or the $\mathrm{H} 3$ history.

2) $\alpha-G p d h$ locus : the history effect is very significant as well as the $\mathrm{G} \times \mathrm{H} \times \mathrm{f}$ interaction (tabl. 2). This inter-history divergence is conspicuous after 5 generations (tabl. 3). However, on account of the important intra-history heterogeneity, it is difficult to conclude that after generation 6 the history effect is not due to random drift. Indeed if we consider the pairs of homogeneous replicates, $\mathrm{H} 1 \mathrm{~B}$ and $\mathrm{H} 1 \mathrm{C}$ on the one hand and $\mathrm{H} 3 \mathrm{~A}$ and $\mathrm{H} 3 \mathrm{~B}$ on the other, the total history effect is just significant at 5 p. $100\left(\chi_{1}^{2}=4.02\right)$, whereas the $\mathrm{G} \times \mathrm{H} \times \mathrm{f}$ interaction $\left(\chi_{6}^{2}=6.25 ; \mathrm{ns}\right)$ and the frequency difference in generation $15\left(\chi_{1}^{2}=0.01 ; \mathrm{ns}\right)$ are not. The appearance of a history effect is due to the divergent replicates : $\mathrm{H} 1 \mathrm{~A}$, in which the $G p d h^{F}$ frequency is the highest (fig. $1 \mathrm{a}$ ), $\mathrm{H} 3 \mathrm{C}$, in which this frequency is the lowest (fig. $1 \mathrm{~b}$ ).

3) Est-6 locus : if the global history effect is manifest, the lack of significance for the $\mathrm{G} \times \mathrm{H} \times \mathrm{f}$ interaction (tabl. 2) denotes an equivalent evolutionary behavior during both histories. The frequency changes seem to be associated with the maintenance of the flies in population cages, a state which constituted a constant factor during the 15 generations of each history. Nevertheless the effect of the E1 and E3 environment appears different for the first 5 generations (tabl. 3).

4) Pgm locus : the absence of significance for the total history effect contrasts with the significance of the $\mathrm{G} \times \mathrm{H} \times \mathrm{f}$ interaction (tabl. 2). This contrast seems to denote a random nature of the frequency changes. The hypothesis is further supported by the fact that in generation 6 the history effect vanished at the same time as the replicate effect in the $\mathrm{H} 1$ history (tabl. 3) and reappeared in generation 15 when the replicate effect became again very important in $\mathrm{H} 1$. 


\section{Discussion}

The study, in the SA-FIV population, of the allozyme frequency behavior in temporally varied environments assigned to verify this behavior in constant environmental conditions and with the least possible competition (KC). This seemed particularly important since the population arrived only a short time before the experiments began. Thus (tabl. 1) a frequency stability was registered for $\alpha-G p d h$ and $E s t-6$ loci, while for $A d h$, and even more for $P g m$, the frequencies varied in a manner that does not seem to be apparently random considering the results of the first 2 loci.

Within both histories, the comparisons of the replicate populations revealed that the temporal observed changes of allozyme frequencies were due in part to random drift. Indeed all loci except $A d h$ displayed within both histories a significant replicate effect. But, depending on the locus, the cause of the intra-history divergence seems to have neither the same origin nor the same consequences. In both histories, from generation 10 onward, this divergence is very substantial for $\alpha-G p d h$ but moderate for Est-6. As for Pgm, the divergence appeared as early as generation 5, remaining substantial after generation 10 in the $\mathrm{H} 1$ history but disappearing after this generation in the $\mathrm{H} 3$ history.

Genetic drift is responsible for 2 outcomes. Primarily, the simple random variations of frequencies affecting all loci. Secondarily, linkage disequilibrium which, if joined with a hitchhiking effect (MAYNARD-Smith \& HAIGH, 1974) can amplify the effects of genetic drift on some loci. On account of, for $\alpha-G p d h$, the great observed heterogeneity and the diversity of the divergent replicates from generation 10 onward, the hypothesis of a hitchhiking effect having affected the $\alpha-G p d h$ frequency changes can be suggested. The consequences of this effect can have varied between replicates according to the importance of the disequilibrium established between the $\alpha-G p d h$ locus and another locus, under selection, tightly linked to it.

An understanding of the relationship between genetic variations at loci encoding enzymes and environmental variations is decisive to any discussion of the role of natural selection in evolution. But actually there is only a small amount of experimental evidence supporting the hypothesis that environmental variation is tracked by allozyme frequencies (HEDRIck et al., 1976). In Drosophila, the main laboratory experiments have investigated the effects of spatial environmental variation (HALEY \& BIRLEY, 1983). In contrast, we have studied the point with respect to the temporal environmental variation. The present results credit a positive response of the $A d h$ locus to environmental conditions. These results include : the frequency homogeneity, contrary to the 3 other loci, observed between replicates within both histories; the increase in $A d h^{F}$ frequency in both histories as opposed to its decrease in the keeping conditions; and finally the sensitivity to the order of the succession of the 3 environments (fig. 5). The sensitivity of this locus to environmental diversity has been previously reported by VAN DELDEN et al. (1978). The principal factors of variation (and perhaps, consequently, of selection) in our environments were the temperature, the nutritive value of the larval culture medium, its humidity level and the addition, or not, of ethanol. And the action of selection on the Adh frequencies by factors such as temperature (McKenzie \& McKechnie, 1981 ; Vigue et al., 1982), humidity (VAN DELDEN et al., 1978) and presence of ethanol (OAKESHOTT \& Gibson, 1981) has been claimed several times, if not demonstrated unambiguously. 
The results observed at the 3 remaining loci seem to be independent of both environmental diversity and of the order of environmental succession. For Pgm, there is no difference between the 2 histories irrespective of generations and the evolutionary behavior is similar in all experiments ( $\mathrm{H} 1, \mathrm{H} 3$ and $\mathrm{KC}$ ). For $\alpha-G p d h$, the appearance of an effect due to the order of the environmental sequence cannot be accepted since it results from an important intra-history divergence, obvious in both histories and probably due to a hitchhiking effect. In addition, such a hitchhiking effect may be the unique cause of the frequency changes in both histories in contrast with the stability registered in the keeping conditions. As for Est-6 in contrast to the stability observed in the keeping conditions, both histories induce a frequency variation, but this variation is independent of the sequence of environments. It seems simply to be associated with the maintenance of the flies in population cages.

In conclusion, the diversity of evolutionary profiles observed in our experiments seems much more important between the 4 loci within the same history than between the 2 histories for the same locus. This suggests that such diversity of the evolutionary profiles results more from the peculiar context of each locus in the genome than from the environmental diversity. It is possible that different kinds of interactions between each locus under consideration and other units of the genome have exerted an impact (as is certainly the case for the $\alpha-G p d h$ locus). This aspect of the eventual role of interacting polymorphic loci on allozyme frequency changes is further broached by MERçoT (1985).

Received January 20, 1984.

Accepted June 21, 1984.

\section{Acknowledgements}

The author wishes to thank Professor C. PETIT for her trust and critical reading of the manuscript, and is very grateful to Professor C. Krimbas for his continuing interest and helpful advice. He thanks Professor J.M. Goux for his advice in statistics, $D^{\mathbf{r}}$ B. Charlesworth for providing the Drosophila population, $\mathrm{D}^{\mathrm{r}} \mathrm{N}$. PAsteur for her comments and, conjointly with $\mathrm{D}^{r} \mathrm{R}$. Wood, for helping with the manuscript. This work was supported by D.G.R.S.T. 3rd Cycle grant $\mathrm{n}^{\circ} 79365$ and E.R.A. 406 C.N.R.S.

\section{References}

Ayala F.J., Powell J.R., Tracey M.L., Mourao C.A., Perez-Salas S., 1972. Enzyme variability in the Drosophila willistoni group. IV. - Genic variation in natural populations of Drosophila willistoni. Genetics, 70, 113-139.

David J., 1959. Etude quantitative du développement de la Drosophile élevée en milieu axenique. Bull. Biol. Fr. Belg., 93, 472-505.

Haley C.S., BiRley A.J., 1983. The genetical response to natural selection by varied environments. II. - Observations on replicate populations in spatially varied laboratory environments. Heredity, 51, 581-606.

Hedrick P.W., Ginevan M.R., Ewing E.P., 1976. Genetic polymorphism in heterogeneous environments. Ann. Rev. Ecol. Syst., 7, 1-32.

IRWIN J.O., 1949. A note on the subdivision of $\chi^{2}$ into components. Biometrika, 36, 130-134. 
Kimball A.W., 1954. Short-cut formulas for the exact partition of $\chi^{2}$ in contingency tables. Biometrics, 10, 452-458.

LANCASTER H.O., 1949. The derivation and partition of $\chi^{2}$ in certain discrete distributions. Biometrika, 36, 117-129.

LANCaster H.O., 1950. The exact partition of $\chi^{2}$ and its application to the problem of pooling of small expectations. Biometrika, 37, 267-270.

Lewontin R.C., 1967. The principle of historicity in evolution. In : Moorhead P.S., KaPlan M.M. (ed), Mathematical Challenges to the Neo-Darwinian Interpretation of Evolution, 81-94, Wistar Institute Press, Philadelphia.

Maxwell A.E., 1961. Analysing qualitative data, 163 pp., Methuen \& Co, London.

Maynard-Smith J., Haigh J., 1974. The hitch hiking effect of a favorable gene. Genet. Res. Camb., 23, 23-35.

Mc Kenzie J.A., Mc Kechnie S.W., 1981. The alcohol dehydrogenase polymorphism in a vineyard cellar population of Drosophila melanogaster. In : GiBSON J.B., OAKESHOTT J.G. (ed), Genetics Studies of Drosophila Populations, 201-216. Australian National University, Canberra.

Merçot H., 1985. A molecular approach to the role of historicity in evolution. I. - Experimental design with enzyme polymorphism in Drosophila melanogaster (submitted to Evolution).

Oakeshott J.G., Chambers G.K., Gibson J.B., Willcocks D.A., 1981. Latitudinal relationships of esterase-6 and phosphoglucomutase gene frequencies in Drosophila melanogaster. Heredity, 47, 385-396.

OAKeshott J.G., Gibson J.B., 1981. Is there selection by environmental ethanol on the alcohol dehydrogenase locus in Drosophila melanogaster? In : GIBSON J.B., OAKESHOTT J.G. (ed.), Genetics Studies of Drosophila Populations, 103-120, Australian National University, Canberra.

Oakeshott J.G., Gibson J.B., Anderson P.R., Knibb W.R., Anderson D.G., Chambers G.K., 1982. Alcohol dehydrogenase and Glycerol-3-phosphate dehydrogenase clines in Drosophila melanogaster on different continents. Evolution, 36, 86-96.

Pearl R., Allen A.L., Penniman W.B.D., 1926. Culture media for Drosophila. II. - A new synthetic medium and its influence on fertility at different densities of population. Am. Nat., 60, 357-366.

Poulik M.D., 1957. Starch gel electrophoresis in a discontinuous system of buffers. Nature, 28, 1477-1479.

Toko M.A., Charlesworth B., 1982. An attempt to detect genetic variation in sex ratio in Drosophila melanogaster. Heredity, 49, 199-210.

Van Delden W., Boerema A.C., Kamping A., 1978. The alcohol dehydrogenase polymorphism in populations of Drosophila melanogaster. I. - Selection in different environments. Genetics, 90, 161-191.

Vigue C.L., Weisgram P.A., Rosenthal E., 1982. Selection at the alcohol dehydrogenase locus of Drosophila melanogaster : effects of ethanol and temperature. Biochem. Genet., 20, 681-688.

WiNer B.J., 1971. Statistical principles in experimental design, 2nd ed., 907 pp., McGrawHill company, New York. 